\title{
EFFECT OF WATER IMMERSION OF SEMI-FINISHED PRODUCTS ON THE FAT CONTENT IN FRIED POTATO PRODUCTS
}

\author{
Zygmunt Sobol* \\ Institute of Machinery Management, Ergonomics and Production Processes, \\ University of Agriculture in Krakow \\ *Corresponding author: e-mail: zygmunt.sobol@ur.krakow.pl
}

\begin{tabular}{|c|c|}
\hline ARTICLE INFO & ABSTRACT \\
\hline $\begin{array}{l}\text { Article history: } \\
\text { Received: April } 2016 \\
\text { Received in the revised form: } \\
\text { June } 2016 \\
\text { Accepted: September } 2016 \\
\end{array}$ & $\begin{array}{l}\text { In this study the influence of selected factors, such as duration of } \\
\text { water sorption resulting from the process of reducing sugars elution } \\
\text { from semi-finished products, temperature of sorbed water, frying } \\
\text { temperature and size of the studied objects (thickness of slices), on the } \\
\text { total fat content in dry mass of the obtained products was analyzed. }\end{array}$ \\
\hline $\begin{array}{l}\text { Key words: } \\
\text { absorption, } \\
\text { fat, } \\
\text { frying, } \\
\text { immersion, } \\
\text { potato }\end{array}$ & $\begin{array}{l}\text { The study was conducted on Innovator cultivar. The scope of the } \\
\text { study encompassed } 5,10,15,20 \text { min water sorption linked to the } \\
\text { process of reducing sugars elution. A control study was also conduct- } \\
\text { ed on samples without the process of reducing sugars elution. Tem- } \\
\text { perature of sorbed water was } 20 \text { and } 40^{\circ} \mathrm{C} \text {; temperature of slice frying } \\
\text { was } 140 \text { and } 180^{\circ} \mathrm{C} \text {; the size of the studied objects, in the experiment } \\
\text { limited by the thickness of slices, was } 4 \text { and } 9 \mathrm{~mm} \text {. Determination of } \\
\text { the total fat content in the products was conducted using the Soxhlet } \\
\text { method. The greatest amount of fat in dry weight was contained in the } \\
\text { products from samples in which sugars were not eluted, when the } \\
\text { process was conducted for a short period of time (several minutes) or } \\
\text { when elution continued for the longest period of time, approx. } 20 \text { min. } \\
\text { The smallest amount of fat was contained in the products from sam- } \\
\text { ples in which the immersion in water was conducted for } 10-15 \text { min. } \\
\text { Thicker slices absorb smaller amounts of fat. Increase of temperature } \\
\text { of sorbed water in the process of extracting sugars from semi-finished } \\
\text { products results in the increase of the total fat content in dry weight of } \\
\text { products. }\end{array}$ \\
\hline
\end{tabular}

\section{Introduction}

Frying is one of the most popular thermal processes of food preparation. During this process, many changes take place in a short period of time; namely, dehydration of the product surface, fat absorption, formation of aromatic compounds and development of color on the surface. Both short preparation time and organoleptic values - taste, aroma, consistency - of the products determine a common usage of the process. Products obtained with this method are very often potato products: fries, crisps. Fat content in fried potato products has an important health and sensory meaning. Too high fat content and poor quality is inadvisable for health reasons because they may lead to formation of numerous metabolic diseases (Billek, 2000; Dobarganes et al., 2000; Saguy and Dana, 2003). For sensory 
reasons both too high and too low fat content are inappropriate. Too high content results in the products not being crunchy enough, giving a greasy sensation. Decreased fat content in the fried potato products, leads to a sense of lack of their characteristic smell and taste (Lisińska, 1994, 2006; Pedreschi and Moyano, 2005).

According to numerous authors, the migration of fat to the product during frying occurs primarily via two mechanisms. The first one is related to the constant fat absorption, resulting from the exchange of water contained in the semi-finished product and fat in which the products are fried. It occurs through the formation of channels in the cellular structure of the semi-finished product due to rapid water evaporation, which after the removal of water are penetrated by fat. The second mechanism occurs directly after finishing the heat treatment and concerns the capillaries absorbing the fat found on the surface of the product, as a result of the under pressure created during the cooling stage (Aguilera and GloriaHernandez, 2000; Bouchon, Aguilera, 2001; Bouchon et al., 2001; Dana, Saguy, 2006; Pedreschi et al., 2008). However, Dana, Saguy, (2006) also indicate that the significant parameter influencing the total fat content in the product is the state of surface of the raw material or semi-finished product, i.e., surfactants sorbing fat.

Therefore, it can be said that a variety of factors influence the fat content in fries and crisps, like raw material properties, semi-finished product preparation and the process of heat treatment of products (Dana, Saguy, 2006; Krokida et al., 2000a; Mellema, 2003; Pedreschi et al., 2008). However, the most significant ones include dry matter content in the raw material (density of the raw material) and necessity for water immersion of semiproducts to elute soluble substances from their surface. Factors influencing fat content in fried products, resulting from the process of heat treatment, are temperature and time of the treatment and type of fat used and its quality conditioned by its freshness level. The shape of the product is also important, as this decides on the mass exchange surface area (in the process of preparation and frying) to produce volume ratio (Friedman, 2000; Krokida et al., 2000b; Moyano, Pedreschi, 2006; Rimac-Brncic et al., 2004).

Another issue related to the production of fried potato products in the context of food safety is the fact that these products contain acrylamide. Presently acrylamide is considered as the latest neurotoxic and carcinogenic substance discovered in food. It is commonly assumed that it is one of the products of Maillard reaction; non-enzymatic browning, which occurs between reducing sugars - glucose, fructose and free asparagine (Friedman, 2003; Mojska et al., 2006, 2009; Szczerbina, 2005; Żyżelewicz et al., 2010). With regard to potato products an efficient process for decreasing its content is by minimizing the level of reducing sugars in the raw material and semi-finished products. There are numerous methods for the limitation of reducing sugars content in semi-finished products, of which the most important are considered to be selection of suitable potato cultivars and maintenance of appropriate storage parameters, especially sufficiently high temperature. One of the equally efficient methods is elution of reducing sugars from semi-finished products in water bath (Cummins et al., 2008; Grob et al., 2003; Jung et al., 2003; Matthaus et al., 2004; Pedreschi et al., 2004; Pedreschi, Moyano, 2005).

Immersed potato semi-products for fries or crisps sorb water dynamically and elution of reducing sugars from their external layer and free starch granules from open cells occur. Sorbed water decreases the density of semi-finished products. Temperature of sorbed water, time of sorption, and the physiological age of tubers impact the dynamics of density changes of the semi-finished products. The shape and size of semi-finished products (from which 
Effect of water immersion...

the sorption surface to object volume ratio results) impacts the process of water sorption too, which in turn influences their density (Sobol, 2006a,b; 2007, 2010).

The aim of the study was to determine the effect on the total fat content in dry mass of the obtained products of such factors as duration of water sorption resulting from the process of reducing sugars elution by semi-finished products, temperature of sorbed water, frying temperature and size of the studied objects - thickness of slices.

\section{Materials and Methods}

The study was conducted on the Innovator cultivar, one of the most popular cultivars used in the production of fries, by both European and Polish companies. It is an early growing type, utilization type B with tubers of a regular shape, round-oval, with shallow eyes, and mean starch content of $14.6 \%$. This cultivar is very resistant to darkening of raw flesh and after cooking it is easily stored.

The scope of the study included:

1. Water sorption time related to the process of reducing sugars elution 5, 10, 15, $20 \mathrm{~min}$. Control experiments were also conducted on samples without the elution of reducing sugars;

2. Temperature of sorbed water was 20 and $40^{\circ} \mathrm{C}$;

3. Temperature of frying slices was 140 and $180^{\circ} \mathrm{C}$;

4. Size of the studied objects in the experiment was limited by the thickness of slices being 4 and $9 \mathrm{~mm}$.

From peeled and washed potatoes, slices with a thickness of 4 and $9 \mathrm{~mm}$ were cut out transversely to the longest axis of the tuber. To specify the parameters of the experiment, the size of slices was restricted to a diameter of $57.3 \mathrm{~mm}$ by cutting out with the use of a punch. Thus, prepared semi-finished products were subjected to the process of reducing sugars elution by immersing them in distilled water with various temperatures and time of treatment. After the process, the objects were drained of the surface water, using a paper kitchen towel. Time of draining was assumed equal for all factors of the experiment. The prepared samples were fried in refined rapeseed oil. Time for frying was established experimentally by performing a trial series that indicated when the obtained products were ready for consumption. Fried samples were drained directly after treatment with the use of a sieve. Samples weighing $100 \mathrm{~g}$ were fried in oil with a volume of $3 \cdot 10^{-3} \mathrm{~m}^{3}$. The obtained products were cooled and then frozen.

Determination of the total fat content was conducted by using extractive-weight Soxhlet apparatus method. The fat content was referred to the dry mass of the product.

The obtained values of the measured fat content in the experiment were verified via the Kolmogorov-Smirnov test and there was no evidence to reject the hypothesis of the normal distribution of the obtained population. To confirm the effect of adopted factors on the studied property of the obtained products, an analysis of variance with multiple classification was used, and for the determination of homogenous groups the Duncan's multiple range test was selected from the post-hoc tests. Changes of the total fat content to the duration of water sorption related to the elution of soluble substances was expressed with models based on the statistical method of non-linear estimation. 
Zygmunt Sobol

\section{Results and Discussion}

\section{Significance of the chosen factors impact}

Results of the analysis of variance in the multiple classification demonstrate that three of the assumed factors, slice thickness, temperature of sorbed water and duration of water sorption, had a statistically significant effect on the change of fat content in dry mass of fried slices. Only temperature of frying did not have a statistically significant effect on the studied parameter. Interactions that proved to be statistically insignificant were temperature of frying - thickness of slice, temperature of frying - temperature of sorbed water, temperature of sorbed water - duration of water sorption and temperature of frying - temperature of sorbed water - duration of water sorption. Remaining interactions were statistically significant (Tab. 1).

The conducted Duncan's multiple range test demonstrated that the following homogenous groups for the total fat content were formed for the following combinations:

1 Group - duration of water sorption 20 and 5 min and control (without sorption) -

$18.85 \%$ and $19.39 \%$ and $19.71 \%$ respectively;

2 Group - duration of water sorption 10 and $15 \mathrm{~min}-17.38 \%$ and $17.81 \%$ respectively;

3 Group - duration of water sorption 15 and $20 \mathrm{~min}-17.81 \%$ and $18.85 \%$ respectively.

Table 1.

Results of univariate significance test; influence of slice frying temperature, slice thickness, temperature of sorbed water and duration of sorption on the changes of fat content in dry mass of fried slices (assumed significance level $\alpha=0.05$ )

\begin{tabular}{lrrrrr}
\hline Qualitative predictor & $\begin{array}{c}\text { Sum } \\
\text { of squares }\end{array}$ & $\begin{array}{c}\text { Degrees of } \\
\text { freedom }\end{array}$ & Mean square & F & p \\
\hline Absolute term & 27761.27 & 1 & 27761.27 & 9809.606 & 0.000000 \\
\hline$\{1\}$ Frying temperature & 3.60 & 1 & 3.60 & 1.271 & 0.266383 \\
\hline$\{2\}$ Slice thickness & 2446.72 & 1 & 2446.72 & 864.564 & 0.000000 \\
\hline$\{3\}$ Temp. of sorbed water & 16.53 & 1 & 16.53 & 5.843 & 0.020294 \\
\hline$\{4\}$ Duration of water sorption & 64.61 & 4 & 16.15 & 5.707 & 0.000989 \\
\hline $1 * 2$ & 7.27 & 1 & 7.27 & 2.568 & 0.116886 \\
\hline $1 * 3$ & 1.30 & 1 & 1.30 & 0.458 & 0.502538 \\
\hline $2 * 3$ & 67.64 & 1 & 67.64 & 23.902 & 0.000017 \\
\hline $1 * 4$ & 122.44 & 4 & 30.61 & 10.816 & 0.000005 \\
\hline $2 * 4$ & 136.83 & 4 & 34.21 & 12.087 & 0.000002 \\
\hline $3 * 4$ & 15.89 & 4 & 3.97 & 1.403 & 0.250338 \\
\hline $1 * 2 * 3$ & 45.83 & 1 & 45.83 & 16.195 & 0.000247 \\
\hline $1 * 2 * 4$ & 289.00 & 4 & 72.25 & 25.530 & 0.000000 \\
\hline $1 * 3 * 4$ & 9.54 & 4 & 2.39 & 0.843 & 0.506351 \\
\hline $3 * 3 * 4$ & 62.40 & 4 & 15.60 & 5.512 & 0.001246 \\
\hline $1 * 2 * 3 * 4$ & 87.28 & 4 & 21.82 & 7.710 & 0.000105 \\
\hline Error & 113.20 & 40 & 2.83 & & \\
\hline & & & &
\end{tabular}

Total fat content in dry mass of fried slices for the assumed frying temperatures amounted to $18.42 \%$ at $140^{\circ} \mathrm{C}$ and $18.84 \%$ at $180^{\circ} \mathrm{C}$, respectively (fig. 1a). 
Effect of water immersion...

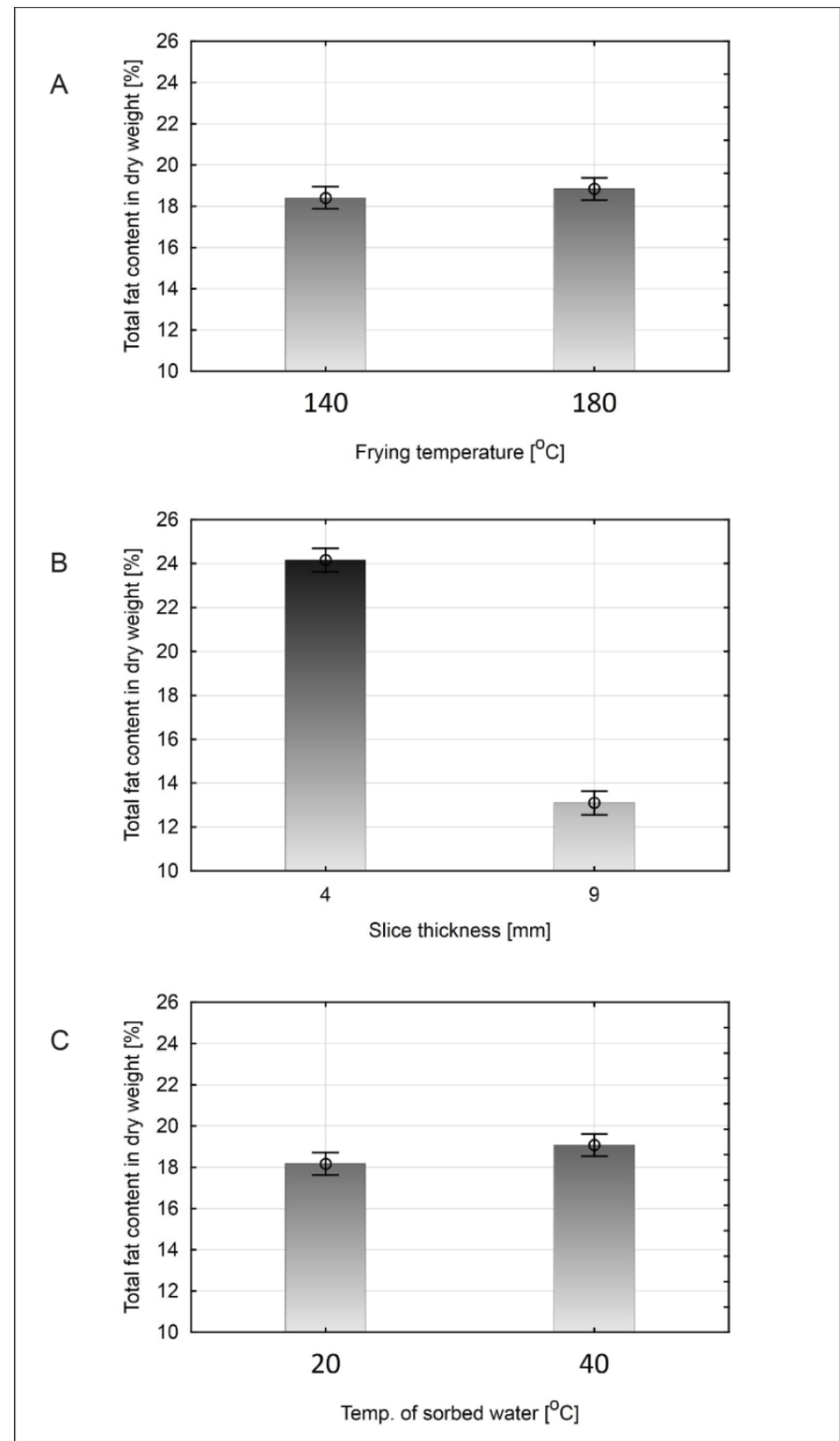

Figure 1. Relation of changes of fat content in dry weight of fried slices: a - to temperature of frying; $b$ - to slice thickness; $c$ - to temperature of sorbed water by semi-finished products in the entire results data 
Obtained data do not entirely coincide with the results of other researchers (TajnerCzopek, 2011), who indicate that with the increase of frying temperature, fat content in the products decreases. However, data obtained by the author of this study in the range of temperature used for treatment presage well in the context of acrylamide content restriction in fried products, because according to numerous studies it is high frying temperature that constitutes one of the main causes for the increase in the content of this compound. Usage of lower frying temperature did not result in significant increase in the fat content.

The slice thickness assumed in the study significantly affected the total fat content in dry weight of fried products (Fig. 1b). $4 \mathrm{~mm}$ slices contained $24.16 \%$ of fat on average while $9 \mathrm{~mm}$ slices contained $13.1 \%$. The cause for this great difference was the significant discrepancy of mass exchange surface of fat to product volume ratio that occurred during frying. For slices of $4 \mathrm{~mm}$ thickness value of this parameter is almost two times higher than that for $9 \mathrm{~mm}$ slices. For a comparable exchange surface in both thicknesses, almost double the quantity of sample mass was taken, which resulted in great changes of fat content in products. What is more, samples with $4 \mathrm{~mm}$ thickness sorbed more water and their density decreased further in comparison to $9 \mathrm{~mm}$ thick samples (Sobol, 2007). Significant difference of density of semi-finished products additionally affected a considerable difference in the total fat content of products.

According to certain researchers, temperature of water bath during the process of reducing sugars elution is important in the context of its efficiency (Grob et al., 2003; Jung et al., 2003; Matthaus et al., 2004; Pedreschi et al., 2004; Pedreschi, Moyano, 2005). Water at the temperatures of 20 and $40^{\circ} \mathrm{C}$ used for immersion of the semi-finished products, at various statistically significant levels, influenced the fat content in fried products (Fig. 1c). Samples, for which water with temperature of $20^{\circ} \mathrm{C}$ was used for the elution of sugars, contained $18.17 \%$ of fat on average, and samples extracted at temperature of $40^{\circ} \mathrm{C}$ contained $19.10 \%$ of fat. Significant difference in the fat content was possibly a result of higher water content (lower density) in samples, which during the immersion in water of higher temperature, absorbed it more. In experiments conducted by the author it was unambiguously determined that the samples of semi-finished potato products soaked in water sorb very intensively, which is expressed by a significant decrease of their density. At the same time, the study exhibited regular decrease of object density together with the increase of temperature of water bath in the range from 20 to $50^{\circ} \mathrm{C}$ (Sobol, 2006a,b; 2007, 2010).

\section{Impact of the water immersion time}

Time of immersion in water is one of the most crucial parameters influencing the effectiveness of the process (Grob et al., 2003; Jung et al., 2003; Matthaus et al., 2004; Pedreschi, Moyano, 2005; Pedreschi et al., 2004). Therefore, the interaction of immersion time and the total fat content in fried potato slices was analyzed with varying time durations, even up to $20 \mathrm{~min}$, thereby determining empirical models on the basis of the statistical method of non-linear estimation (Tab. 2). Determined models are well matched to the real values obtained from the empirical study. Calculated variance participation explained for the determined models ranged between 0.479 and 0.968 . These interactions encompass the influence of the duration of sorption of water by semi-finished products during blanching (water sorption) on the total fat content in fried products, within the entire results data and in individual ranges of values dependent on the influence of the remaining factors (Tab. 2). 
Effect of water immersion...

Table 2.

Parameters of estimated function of changes in fat content in dry mass of fried slices depending on duration of water sorption by semi-finished products within assumed factors of experiment

\begin{tabular}{llcccc}
\hline & \multicolumn{1}{c}{ Elements } & \multicolumn{3}{c}{ Estimated function $\mathrm{y}=\mathrm{a}_{1} \cdot \mathrm{x}^{2}+\mathrm{a}_{2} \cdot \mathrm{x}+\mathrm{a}_{3}$} \\
\cline { 3 - 6 } No. & \multicolumn{3}{c}{ Function parameters } & $\begin{array}{c}\text { Explained } \\
\text { variance share }\end{array}$ \\
\cline { 3 - 6 } & All factors & 0.014697 & -0.36004 & 20.0243 & 0.739 \\
2 & Frying temperature $140^{\circ} \mathrm{C}$ & 0.018864 & -0.39186 & 19.5053 & 0.479 \\
3 & Frying temperature $180^{\circ} \mathrm{C}$ & 0.027672 & -0.55108 & 20.2004 & 0.784 \\
4 & Slice thickness $4 \mathrm{~mm}$ & 0.033712 & -0.84186 & 27.5205 & 0.968 \\
5 & Slice thickness $9 \mathrm{~mm}$ & 0.024253 & -0.64964 & 16.9566 & 0.829 \\
6 & Temp. of sorbed water $20^{\circ} \mathrm{C}$ & 0.022735 & -0.51896 & 19.953 & 0.777 \\
7 & Temp. of sorbed water $40^{\circ} \mathrm{C}$ & 0.006658 & -0.20112 & 20.0956 & 0.529 \\
\hline
\end{tabular}

The analysis of changes of fat content during the experiment time of water sorption shows that fried products attained minimal amount of fat within the time range of 10-15 min during the process (Fig. 2a,b,c,d).

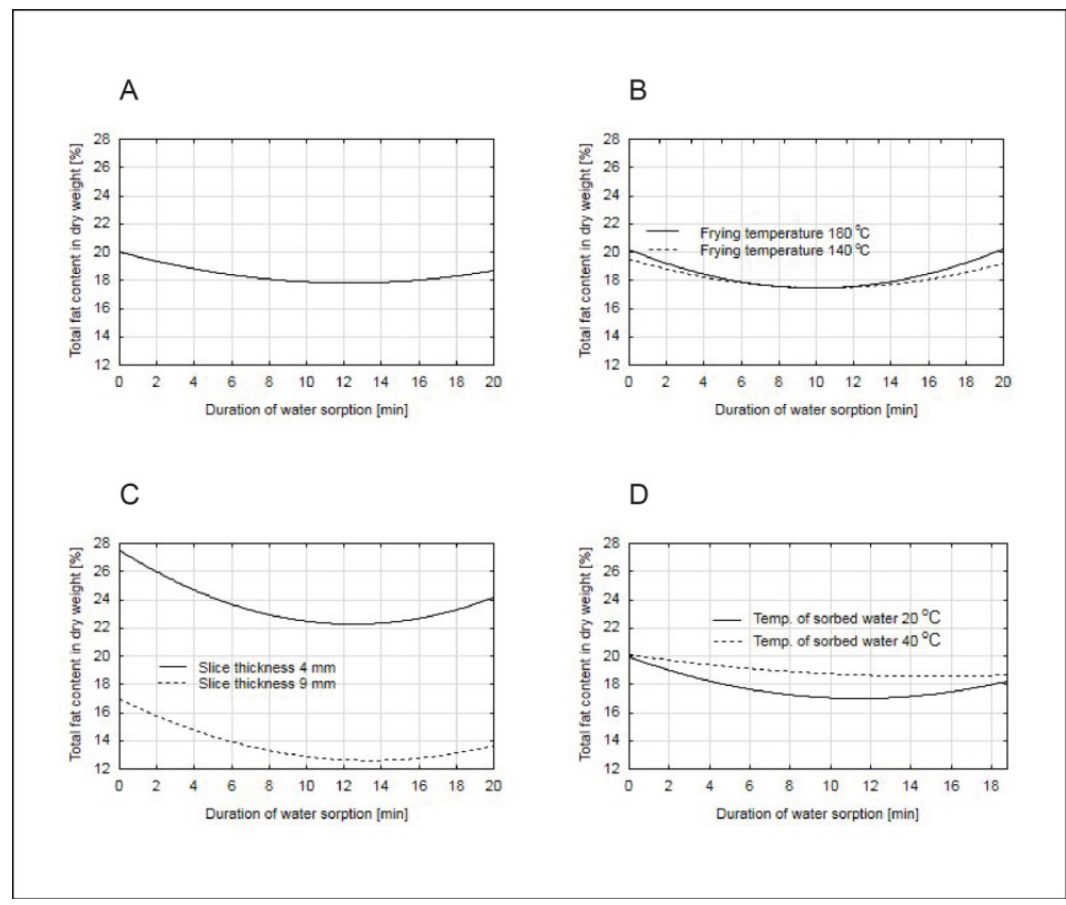

Figure 2. Relation of changes of fat content in dry mass of fried slices to duration of water sorption by semi-finished products: $a$ - within the entire results data; $b$ - within frying temperature of 140 and $180^{\circ} \mathrm{C}$; $c$-for slice thickness of 4 and $9 \mathrm{~mm}$; $d$-within temperature of sorbed water of 20 and $40^{\circ} \mathrm{C}$ 
Lack of water immersion and short time of the process (up to several minutes) as well as its prolongation to $20 \mathrm{~min}$ resulted in the increase of fat content in products. Such changes of fat content were probably influenced by all phenomena accompanying the process of fat absorption by fried products (Aguilera, Gloria-Hernandez, 2000; Bouchon, Aguilera, 2001; Bouchon et al., 2001; Dana, Saguy, 2006; Pedreschi et al., 2008). In control samples (without immersion in water), the level of fat content in the products was determined by the state of the surface of semi-finished products as well as with the short time of immersion. From the surfaces not subject to extraction and those subject to short extraction, the free exposed starch granules, which appeared in great number due to modeling and slicing of semifinished products, were not removed (washed). Such a state of the surface probably determined the large fat content in these samples, despite greater density of these semi-finished products as compared with the remaining samples (Fig. 2a,b,c,d). The lowest fat content in products obtained from samples in which extraction of reducing sugars lasted for approx. 10-15 min (and therefore samples sorbed water during this time) was linked to a comparatively efficient washing of free starch granules and relatively small decrease of semifinished product density at the same time (Sobol, 2006a,b; 2007, 2010). Prolongation of sugar extraction to $20 \mathrm{~min}$ resulted in a significant decrease of semi-finished product density (significant increase of absorbed water level), and therefore increase of fat content in products (Sobol, 2006a,b; 2007, 2010). Increase of fat content in these samples was a result of, primarily, the exchange of absorbed water from fat to semi-finished product (Fig. 2a,b,c,d).

The analysis of changes of fat content dependent on the duration of water sorption within the influence of the remaining assumed factors of the experiment shows that the greatest influence on the studied characteristic was the thickness of studied slices. This dependence is confirmed by the two-dimensional models presented in this study, in which the dependent variable was the total fat content in dry mass, and independent variables were the water sorption time on the remaining parameters of the experiment (Tab. 3, Fig. 3a,b,c). Obtained slope of the plane expressing changes of the total fat content depending on water sorption time and slice thickness exhibits a significant effect of both factors, especially the second mentioned (Fig. 3b). The two-dimensional models explain the simultaneous effect of water sorption time and temperature of frying and temperature of sorbed water, which confirms that these factors have a lesser effect on the process of fat absorption during frying (Table 3) (Fig. 3a,c).

Table 3

Parameters of estimated function of changes of fat content in dry mass of fried slices depending on duration of water sorption and the remaining factors of experiment

\begin{tabular}{llcccc}
\hline & & \multicolumn{4}{c}{ Estimated function $\mathrm{z}=\mathrm{a}_{1} \cdot \mathrm{x}+\mathrm{a}_{2} \cdot \mathrm{y}+\mathrm{a}_{3}$} \\
\cline { 3 - 6 } No. & \multicolumn{2}{c}{ Elements } & \multicolumn{2}{c}{$\begin{array}{c}\text { Function } \\
\text { parameters }\end{array}$} & \multicolumn{2}{c}{$\begin{array}{c}\text { Explained } \\
\text { variance share }\end{array}$} \\
& $\mathrm{a}_{1}$ & $\mathrm{a}_{2}$ & $\mathrm{a}_{3}$ & \\
\hline 1 & Duration of water sorption - Frying temperature & 0.0106 & -0.0661 & 17.5934 & 0.029 \\
2 & Duration of water sorption - Slice thickness & -2.2121 & -0.0661 & 33.6682 & 0.936 \\
3 & $\begin{array}{l}\text { Duration of water sorption - Temp. of sorbed } \\
\text { water }\end{array}$ & 0.0455 & -0.0661 & 17.9256 & 0.350 \\
\hline
\end{tabular}


Effect of water immersion...

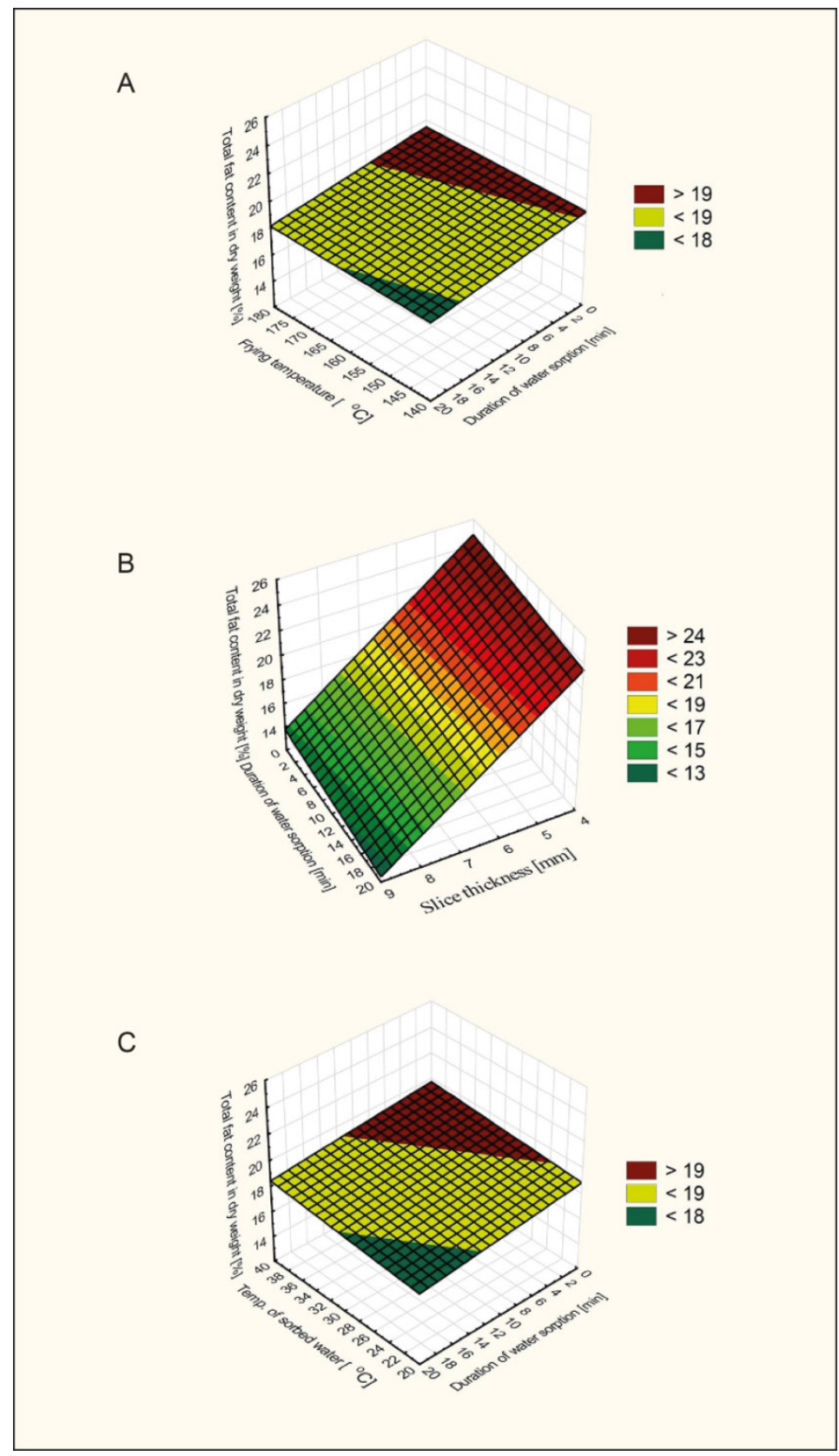

Figure 3. Relation of changes of fat content in dry mass of fried slices to duration of water sorption by semi-finished products and: $a$ - frying temperature; $b$ - slice thickness; $c$-temperature of sorbed water 
Zygmunt Sobol

\section{Conclusion}

1. The total fat content in dry mass of fried potato slices is statistically significantly by thickness of slices, temperature and duration of water sorption by semi-finished products during water immersion.

2. Thicker slices absorb smaller amounts of fat.

3. Increase of the sorbed water temperature in the water immersion process of semifinished products results in the increase of the total fat content in dry weight of the products.

4. The greatest amount of fat in dry weight is contained in the products from samples not immersed in water in soluble substances were not eluted from surface, where the process was conducted for a short period of time (several minutes) or when water sorption continued for the longest period of time, approx. $20 \mathrm{~min}$.

5. The lowest amount of fat is contained in products from samples in which the water sorption process was conducted for 10 to $15 \mathrm{~min}$.

\section{References}

Aguilera, J.M., Gloria-Hernandez, H. (2000). Oil Absorption During Frying of Frozen Parfried Potatoes. Journal of Food Science, 65(3), 476-479.

Billek, G., (2000). Health aspects of thermoxidized oils and fats. European Journal of Lipid Science and Technology, 102, 587-593.

Bouchon, P., Aguilera, J. M. (2001). Microstructural analysis of frying potatoes. International Journal of Food Science and Technology, 36, 669-676.

Bouchon, P., Hollins, P., Pearson, M., Pyle, D.L., Tobin, M.J. (2001). Oil Distribution in Fried Potatoes Monitored by Infrared Microspectroscopy. Journal of Food Science, 66(7), 918-923.

Cummins, E., Butler, F., Gormley, R., Brunton, N. (2008). A methodology for evaluating the formation and human exposure to acrylamide through fried potato crisps. LWT-Food Science and Technology, 41, 854-867.

Dana, D., Saguy, I. S. (2006). Mechanism of oil uptake during deep-fat frying and the surfactant effect-theory and myth. Advances in Colloid and Interface Science, 128-130, 267-272.

Dobarganes, C., Márquez-Ruiz, G., Velasco, J. (2000). Interactions between fat and food during deepfrying. European Journal of Lipid Science and Technology, 102, 521-528.

Friedman, B. (2000). Adsorbent antioxidant provides optimum frying in restaurant and fast food fryers. European Journal of Lipid Science and Technology, 102, 560-565.

Friedman, M. (2000). Chemistry, Biochemistry, and Safety of Acrylamide. A Review. Journal of Agricultural and Food Chemistry, 51, 4504-4526.

Garayo, J., Moreira, R. (2002).Vacuum frying of potato chips. Journal of Food Engineering, 55, 181191.

Grob, K., Biedermann, M., Biedermann-Brem S., Noti, A., Imhof, D., Amrein, T., Pfefferle, A., Bazzocco, D. (2003). French fries with less than $100 \mathrm{mg} / \mathrm{kg}$ acrylamide. A collaboration between cooks and analysts. European Food Research and Technology, 217, 185-194.

Jung, M. Y., Choi, D. S., Ju, J. W. (2003), A novel technique for limitation of acrylamide formation in fried and baked corn chips and in French fries. Journal of Food Science, 68, 1287-1290.

Krokida, M.K., Oreopoulou, V., Maroulis, Z.B. (2000a). Effect of frying conditions on shrinkage and porosity of fried potatoes. Journal of Food Engineering, 43, 147-154.

Krokida, M.K., Oreopoulou, V., Maroulis, Z.B. (2000b). Water loss and oil uptake as a function of frying time. Journal of Food Engineering, 44, 39-46. 
Effect of water immersion...

Lisińska, G. (1994). Ziemniak jako surowiec dla przemysłu. Wymagania w stosunku do surowca. Zeszyty Problemowe Postęów Nauk Rolniczych, 1, 32-40.

Lisińska, G. (2006). Wartość technologiczna i jakość konsumpcyjna polskich odmian ziemniaka Zeszyty Problemowe Postępów Nauk Rolniczych, 511(1), 81-94.

Matthaus, B., Haase, N. U., Vosmann, K. (2004) Factors affecting the concentration of acrylamide during deep-fat frying of potatoes. European Journal of Lipid Science Technology, 106, 793-801.

Mellema, M. (2003). Mechanism and reduction of fat uptake in deep-fat fried foods. Trends in Food Science \& Technology, 14, 364-373.

Mojska, H., Gielecińska, I., Chajewska, K., Szponar, L. (2006). Chipsy jako potencjalne źródło akryloamidu w polskiej diecie. Zdrowie Publiczne, 116(2), 353-355.

Mojska, H., Gielecińska, I., Ołtarzewski, M., Szponar, L. (2009). Akryloamid w żywności-ocena narażenia populacji polskiej. Bromatologia i Chemia Toksykologiczna, XLII (3), 436-441.

Moyano, P. C., Pedreschi, F. (2006). Kinetics of oil uptake during frying of potato slices: Effect of pre-treatments. LWT-Food Science and Technology, 39, 285-291.

Pedreschi, F., Cocio, C., Moyano, P., Troncoso, E. (2008). Oil distribution in potato slices during frying. Journal of Food Engineering, 87, 200-212.

Pedreschi, F., Moyano, P. (2005). Oil uptake and texture development in fried potato slices. Journal of Food Engineering, 70, 557-563.

Pedreschi, F., Kaack, K., Granby, (2004). K. Reduction of acrylamide formation in potato slices during frying. Lebensmittel-Wissenschaft and Technologie, 37, 679-685.

Rimac-Brncic, S., Lelas, V., Rade, D., Simundic, B. (2004). Decreasing of oil absorption in potato strips during deep fat frying. Journal of Food Engineering, 64, 237-241.

Saguy, I. S., Dana, D. (2003). Integrated approach to deep fat frying: engineering, nutrition, health and consumer aspects. Journal of Food Engineering, 56, 143-152.

Sobol, Z. (2006a). Zmiana ubytku gęstości bulw ziemniaka w wyniku absorpcji wody. Acta Agrophysica, 8(4), 985-993.

Sobol, Z. (2006b). Wpływ wybranych czynników na gęstość bulw ziemniaka. Acta Agrophysica, 8(1), 219-228.

Sobol, Z. (2007). Zmiany ubytków gęstości słupków i plastrów wyciętych z bulw ziemniaka wynikające z absorpcji wody. Acta Agrophysica, 10(1), 219-228.

Sobol, Z. (2010). Wpływ temperatury sorbowanej wody przez półprodukty na frytki na zmianę ich gęstości. Acta Agrophysica, 16(2), 435-450.

Szczerbina, T. (2005). Akrylamid - potencjalnie rakotwórcza substancja występująca w żywności. Kosmos. Problemy Nauk Biologicznych, 54(4), 367-372.

Tajner-Czopek, A. (2011). Wpływ zabiegów technologicznych na właściwości frytek ziemniaczanych $i$ zawartość akrylamidu. Wydawnictwo Uniwersytetu Przyrodniczego we Wrocławiu. Wrocław.

Truong, V.-D., Pascua, Y. T., Reynolds, R., Thompson, R. L., Palazoğlu, T. K., Mogol, B. A., Gokmen, V. (2014). Processing Treatments for Mitigating Acrylamide Formation in Sweetpotato French Fries. Journal of Agricultural and Food Chemistry, 62, 310-316.

Żyżelewicz, D., Nebesny, E., Oracz, J. (2010). Akrylamid-powstawanie, właściwości fizykochemiczne i biologiczne. Bromatologia i Chemia Toksykologiczna, XLIII(3), 415-427. 


\section{WPLYW ZANURZENIA W WODZIE PÓLPRODUKTÓW NA ZAWARTOŚĆ TŁUSZCZU W PRODUKTACH SMAŻONYCH Z ZIEMNIAKA}

Streszczenie. Praca niniejsza analizuje wpływ wybranych czynników, takich jak, czas trwania sorpcji wody, która wynika z procesu elucji cukrów redukujących z półproduktów, temperatura wchłoniętej wody, temperatura smażenia oraz rozmiar badanych obiektów (grubość plastrów) na ogólną zawartość thuszczu w suchej masie otrzymanych produktów. Badania przeprowadzono na odmianie Innovator. Zakres badań dotyczył 5, 10, 15 i 20 minutowej sorpcji wody związanej z procesem elucji cukrów redukujących. Temperatura sorbowanej wody wynosiła 20 i $40^{\circ} \mathrm{C}$; temperatura smażenia plastrów wynosiła 140 i $180^{\circ} \mathrm{C}$; rozmiar badanych obiektów, w doświadczeniu określonych przez ich grubość, wynosił 4 i $9 \mathrm{~mm}$. Ogólna zawartość tłuszczu została określona za pomocą metody Soxhlet. Najwyższa zawartość tłuszczu w suchej masie występowała w przypadku próbek, w których cukier nie został wymyty, kiedy proces trwał krótko, lub gdy wymywanie trwało najdłużej, około 20 minut. Najmniejsza ilość tłuszczu wystąpiła w przypadku próbek zanurzonych w wodzie przez 10-15 minut. Grubsze plastry absorbują mniej thuszczu. Zwiększenie temperatury sorbowanej wody w procesie ekstrakcji cukrów z półproduktów powoduje wzrost ogólnej zawartości tłuszczu w suchej masie produktu.

Słowa kluczowe: absorpcja, tłuszcz, smażenie, zanurzenie, ziemniak 